\title{
Comparison of different cytogenetic methods and tissue suitability for the study of chromosomes in Cimex lectularius (Heteroptera, Cimicidae)
}

\author{
David Sadílek', Robert B. Angus², František Štáhlavský', Jitka Vilímová' \\ I Charles University in Prague, Faculty of Science, Department of Zoology, Viničná 7, CZ-12844 Praha, \\ Czech Republic 2 Department of Life Sciences (Entomology), The Natural History Museum, Cromwell Road, \\ London SW7 5BD, UK
}

Corresponding author: David Sadilek (sadilek11@volny.cz)

Academic editor: S. Grozeva | Received 29 September 2016 | Accepted 30 October 2016 | Published 14 December 2016

http://zoobank.org/090872DE-C6C7-4AC9-AC78-FA441E234A08

Citation: Sadílek D, Angus RB, Štáhlavský F, Vilímová J (2016) Comparison of different cytogenetic methods and tissue suitability for the study of chromosomes in Cimex lectularius (Heteroptera, Cimicidae). Comparative Cytogenetics 10(4): 731-752. https://doi.org/10.3897/CompCytogen.v10i4.10681

\begin{abstract}
In the article we summarize the most common recent cytogenetic methods used in analysis of karyotypes in Heteroptera. We seek to show the pros and cons of the spreading method compared with the traditional squashing method. We discuss the suitability of gonad, midgut and embryo tissue in Cimex lectularius Linnaeus, 1758 chromosome research and production of figures of whole mitosis and meiosis, using the spreading method.

The hotplate spreading technique has many advantages in comparison with the squashing technique. Chromosomal slides prepared from the testes tissue gave the best results, tissues of eggs and midgut epithelium are not suitable. Metaphase II is the only division phase in which sex chromosomes can be clearly distinguished. Chromosome number determination is easy during metaphase I and metaphase II. Spreading of gonad tissue is a suitable method for the cytogenetic analysis of holokinetic chromosomes of C. lectularius.
\end{abstract}

\section{Keywords}

holokinetic chromosomes, spreading method, squashing method, testes, midgut, karyogram

Copyright David Sadilek et al. This is an open access article distributed under the terms of the Creative Commons Attribution License (CC BY 4.0), which permits unrestricted use, distribution, and reproduction in any medium, provided the original author and source are credited. 


\section{Introduction}

Insect chromosome research is more than 130 years old (White 1973). Large polytene chromosomes of Diptera (Chironomus spp., Drosophila spp., Sciara spp.) were the first subjects studied (e.g. Korschelt 1884, Koller 1935). Gradually, cytogenetic studies became more and more common, so that now insect cytogenetics is a well-established field of science using various modern enhanced methods (e.g. Cabral-de-Mello et al. 2010, Novotná et al. 2011, van't Hof et al. 2011, Bueno et al. 2013).

Historically, classical histology was the first method used for preparing arthropod chromosomes, including insect ones, when the tissue in paraffin wax was cut into sections 7-20 microns in thickness (McClung 1899, Montgomery 1901, Darlington 1939, Slack 1939, Parshad 1957, Piza 1957, and others). This method is no longer used for study of insect chromosomes. The next method developed was a squashing technique (Sáez 1950), which began to be widely used in second half of the $20^{\text {th }}$ century (e.g. Leston 1957, Piza 1957, Warren et al. 1960, Ueshima 1963) and it is still considered as a classical method by the majority of insect cytogeneticists including heteropterologists (e.g. Bressa et al. 2002a, 2003, Poggio et al. 2006, Grozeva et al. 2010, Yang et al. 2012).

The most recent method "hotplate spreading" (only spreading hereinafter) was originally used only for vertebrate chromosomes studies. The whole method was then modified by Crozier (1968) and used also for insect chromosome research (namely ants and dipterans). Traut (1976) developed other modifications of the spreading for lepidopteran chromosome analysis. Recently, this method has been used more frequently not only for study of chromosomes of various insect taxa (Bressa et al. 2009, 2015, van't Hof et al. 2011, Paladino et al. 2013, Sadílek et al. 2013, Chirino et al. 2015) but also for all other main arthropod evolutionary lineages such as arachnids (e.g. Štáhlavský and Král 2004, Forman et al. 2013, Adilardi et al. 2014, Sadílek et al. 2015), myriapods (e.g. Green et al. 2016), and crustaceans (e.g. Kořínková and Goldyn 2011).

However, the use of the squashing method still strongly prevails over spreading in present Heteroptera cytogenetic studies. As the first, Angus (1982) optimised spreading after Crozier (1968) and applied it for chromosome analysis of Hydrophilidae (Coleoptera). Angus routinely used colchicine to block spindle formation. Later, this method was used in the study of the nepomorphan families Notonectidae (Angus et al. 2004) and Corixidae (Waller and Angus 2005). The spreading technique was also modified by Traut (1976) for male and female meiotic studies in lepidopteran species. Following his procedure, spreading was used successfully for chromosome studies of other heteropteran taxa, namely Corixidae: Micronectinae (Ituarte and Papeschi 2004), Reduviidae: Hammacerinae (Poggio et al. 2011), Triatominae (Morielle-Souza and Azeredo-Oliveira 2007, Poggio et al. 2013a), Reduviinae (Poggio et al. 2013b), Coreidae (Bressa et al. 2008), Pyrrhocoridae (Bressa et al. 2009), and Belostomatidae (Bardella et al. 2012, Chirino et al. 2013, 2014).

One of the very frequently studied Heteroptera is the obligatorily ectoparasitic genus Cimex Linnaeus, 1758 (Cimicidae), which includes parasitologically and medi- 
cally important species. This genus is characterised by possession of the all-important heteropteran cytogenetic features: holokinetic chromosomes (e.g. Wolf et al. 1997, Mola and Papeschi 2006, Papeschi and Bressa 2006, Guerra et al. 2010, Poggio et al. 2014), achiasmatic male meiosis of collochore type (Nokkala and Nokkala 1983, Nokkala and Grozeva 2000, Grozeva and Nokkala 2002, Ituarte and Papeschi 2004, Grozeva et al. 2008, 2010, Poggio et al. 2009, 2014, Kuznetsova et al. 2011), postreductional inverted male sex chromosome meiosis (Viera et al. 2009, Kuznetsova et al. 2011), and the diffuse stage (Kuznetsova and Maryańska-Nadahowska 2000, Bressa et al. 2002b, Rebagliati et al. 2005, Lanzone and Souza 2006). However the cytogenetic research on Cimex species is difficult because of some other chromosome characteristics, such as the small size, high morphological similarity and superspiralization during almost the whole period of chromosomal division (e.g. Ueshima 1966, Manna 1984). Holokinetic chromosomes lack a primary constriction and thus a localized centromere, which facilitates structural rearrangements of the karyotype by nonlethal chromosomal fusions and fragmentations. Fusions in this type of chromosomes do not result in dicentric chromosomes. Chromosome fragments are able to attach to spindle fibres and migrate normally during mitosis or meiosis, which enables them to go through further cell division (e.g. Motzko and Ruthmann 1984, Howe et al. 2001, Mandrioli and Manicardi 2003, Schvarzstein et al. 2010).

In addition to the above mentioned features, the important human ectoparasite model species Cimex lectularius Linnaeus, 1758 shows intraspecific variability in number of sex chromosomes from three $\left(\mathrm{X}_{1} \mathrm{X}_{2} \mathrm{Y}\right)$ to $21\left(\mathrm{X}_{1} \mathrm{X}_{2} \mathrm{Y}+18\right.$ extra $\left.\mathrm{Xs}\right)$ (e.g. Darlington 1939, Slack 1939, Ueshima 1966, Sadílek et al. 2013). In the family Cimicidae, the sex is determined by the presence of an XX/XY (female/male) simple sex chromosome system in 53 cytogenetically analysed species. Most cimicid species, including the majority of Cimex species, also possess a multiple sex chromosome system $\mathrm{X}_{1} \mathrm{X}_{1} \mathrm{X}_{2} \mathrm{X}_{2}$ / $\mathrm{X}_{1} \mathrm{X}_{2} \mathrm{Y}$ (except $C$. antennatus Usinger \& Ueshima, 1965, C. latipennis Usinger \& Ueshima, 1965 and C. incrassatus Usinger \& Ueshima, 1965 with the basic XX/XY system) (Poggio et al. 2009, Grozeva et al. 2010, Kuznetsova et al. 2011, Sadílek et al. 2013). Four cimicid species possess constantly three $X$ chromosomes $\left(X_{1} X_{2} X_{3} Y\right.$, male) (Paracimex capitatus Usinger, 1966, P. inflatus Ueshima, 1968, P. philippinensis Usinger, 1959 and Hesperocimex coloradensis List, 1925) and two species four X chromosomes $\left(\mathrm{X}_{1} \mathrm{X}_{2} \mathrm{X}_{3} \mathrm{X}_{4} \mathrm{Y}\right.$, male) (Cimex adjunctus Barber, 1939 and C. brevis Usinger \& Ueshima, 1965) (Ueshima 1979, Kuznetsova et al. 2011).

Intraspecific variability in the number of $\mathrm{X}$ chromosomes has been described in three cimicid species from the subfamily Cimicinae, Paracimex borneensis Usinger, 1959 (2X; 5-9X), P. capitatus (2-6X) and C. lectularius (2-20X) (summary in Ueshima $1966,1968,1979)$. The numbers of $C$. lectularius X chromosomes can differ among different populations (localities), or among specimens within one population. Even a single specimen can contain cells with different numbers of X chromosomes (Ueshima 1966, 1979, Sadílek et al. 2013). Preliminary study has also indirectly indicated the possibility of a variable number of $\mathrm{X}$ chromosomes in an obligatory bat parasite Cimex pipistrelli Jenys, 1839 (Sadílek et al. 2013). Therefore, it seems possible that intraspe- 
cific variability of $\mathrm{X}$ chromosomes could be a general feature of the genera Cimex and Paracimex Kiritshenko, 1913, or even possibly a wider spectrum of Cimicidae species.

Cimex lectularius became an intensively studied species by a wide spectrum of scientific approaches due to its recent massive global expansion (e.g. Hwang et al. 2005, Romero et al. 2007, Reinhardt et al. 2008, Weeks et al. 2010, Balvín et al. 2012, Booth et al. 2015), including cytogenetic studies using modern methods by Grozeva et al. (2010, 2011) and the detailed analysis of variable karyotype by Sadílek et al. (2013). As it is generally very important to improve methodological approach to research, we used the spreading method for preparing C. lectularius chromosome slides.

The main aim of the present study is to compare results of the spreading method, used for the first time in the Cimicidae, with the traditional squashing method. We aimed to find out if the spreading method resulted in different or more conclusive data and could be therefore more suitable for analysis of cimicid holokinetic chromosomes. The use of spreading is currently quite rare even within researches of other Heteroptera species but it is also recommended for cytogenetic studies of the other insect orders. The present paper also makes comparisons of the suitability of different tissues for cytogenetic study, and of distinct cell division phases, chromosome size measurement and assembly of C. lectularius karyograms.

\section{Material studied and equipment used}

\section{Material studied}

220 specimens of $C$. lectularius collected from 65 localities in 10 European countries in the period 2010-2012 were studied, for geographical origins see Sadílek et al. (2013). Live specimens were mostly collected by pest exterminators from human dwellings. They were either studied immediately or were kept alive in the refrigerator at $4{ }^{\circ} \mathrm{C}$ without any blood meal. They could survive in good health in such conditions even more than a half of year. Gonad tissue from 115 adult males, 81 adult females and 24 larvae was studied cytogenetically. From those specimens 116 slides of mesenteron (1 slide per specimen) and 13 slides of eggs/embryos (1 slide from a few eggs per female) were also analysed.

\section{Equipment used}

The chromosome slides were examined using the Olympus Provis AX 70 light microscope and selected cells and stages of division were documented by the digital imaging system Olympus DP 72 and software QuickPHOTO CAMERA 2.3. Karyograms were made in graphic editor Corel DRAW X5. For assembly of karyograms, chromosomes were cut out from photographs, measured and sorted by size in software ImageJ 1.47 with Levan plugin (http://imagej.nih.gov/ij/). 


\section{Results and discussion}

\section{Hotplate spreading}

The basic principle of the hotplate spreading technique is to turn extracted tissue into a suspension and let cells to adhere to the surface of a microscope slide (optimal is SuperFrost quality slide) as the drop was moved on the slide by pushing it with fine tungsten needles and evaporated. The resulting semipermanent slide (without cover slip) is characterized by its long durability (for years), stored at $4{ }^{\circ} \mathrm{C}$ for basic Giemsa staining or $-20{ }^{\circ} \mathrm{C}$ to $-80{ }^{\circ} \mathrm{C}$ for further molecular analysis (e.g. FISH). Cimex lectularius specimens were dissected in hypotonic solution $0.075 \mathrm{M} \mathrm{KCl}$ immediately after killing, to keep the gonad tissue hydrated and remove debris of other tissues. During hypotonisation, the cells receive additional water due to osmosis, making them larger, the contents of the cell are loosened and chromosomes become more individualized. Chromosomes can be damaged or washed away during final dissociation in case of excessive hypotonic treatment. However, chromosomes are still too compact and are not analysable in insufficiently hypotonised cells. Several time periods of tissue hypotonisation were tried: 10, 15, 20, 25 and 30 minutes. The best results were obtained from samples after 25 minutes of fresh hypotonic solution treatment.

Tissue fixation in methanol: glacial acetic acid 3:1 was the next step, methanol can be replaced by $99.9 \%$ ethanol. Alcohol causes immediate death of cells and acetic acid penetrates the membrane for quick ideal preservation of inner structures especially chromosomes. Two types of fixation were tested, one step fixation for 5, 10, 15 or 20 minutes, and two step fixation for $5+10$, or $10+20$ minutes. However, the duration of fixation had a minor effect on the final quality of chromosomes on slides. Two step fixation for $5+10 \mathrm{~min}$ utes was found to be optimal, the tissue dehydration effectiveness increased because in the second fixation step dilution by water from hypotonic solution was reduced to minimum.

Fixed tissue was mechanically suspended on the slide with tungsten needles and cells were chemically released by adding of $1-2$ drops of $60 \%$ acetic acid. Undissociated clusters of tissue were removed. The slides with suspension were put on a warm $\left(45^{\circ} \mathrm{C}\right)$ histological plate and the drop was moved all around the slide with the needle. Adhering cells can create hardly diagnosable clusters without that movement. The chromosome sets are very often overlapping in those clusters. Suspension movement also contributes to evenly distributed chromosomal material on the slide surface. The slides were stained on the second day, allowing them to dry properly and to avoid loss of chromosomes. The staining was carried out using a 5\% Giemsa solution in Sörensen phosphate buffer ( $\mathrm{pH}=6.8$ ) for $10,15,20,30$ or 40 minutes (optimum in 30 minutes). The stained slides were stored in a refrigerator at $4{ }^{\circ} \mathrm{C}$. The mechanism of cell adherence is described in detail by Imai et al. (1988).

The squashing technique is the more widely used method in Heteroptera cytogenetics. Usually, living specimens are directly fixed in ethanol: glacial acetic acid or methanol: glacial acetic acid (3:1) and can be stored at $4{ }^{\circ} \mathrm{C}$ for later use. Dissected gonad tissue is squashed under a cover slip in a drop of $45 \%$ acetic acid, which is then frozen using dry ice (solid $\mathrm{CO}_{2}$ ) (e.g. Kuznetsova and Nadachowska 2000, Grozeva 
et al. 2010, Kuznetsova et al. 2015), or freezing in liquid nitrogen (e.g. Pérez et al. 2004, Bardella et al. 2010) to allow removal of the coverslip. There are also frequent modifications of squashing method for example with use of acetic haematoxylin (e.g. Bressa et al. 2005) or iron propionic haematoxylin (e.g. Rebagliati et al. 2001). After removing cover slips with a razor blade, the slides are dehydrated in fresh fixative for 15 min and air-dried (e.g. Grozeva and Nokkala 2002, Grozeva et al. 2010). The slides are stained with Feulgen Giemsa (e.g. Grozeva and Nokkala 1996).

An undoubted advantage of the squashing method is a possibility to fix material right in the field and then keep it in $70 \%$ ethanol at $4{ }^{\circ} \mathrm{C}$ for a long time (months, years), but the gonads kept longer period in cold become harder and the squashing of tissue would be more difficult. Material cannot be preserved before use of spreading method, because chromosomes from fixed cells cannot be spread. The major advantage of spreading is easier methodology. In particular, independence of dry ice or liquid nitrogen (hard to supply in the field) makes it possible to use this method outside the laboratory, with the only demand being for electricity or even without hotplate at the room temperature - higher temperature fasten the evaporation and the efficiency of the plate spreading technique.

The spreading needs manual skill in suspension droplet movement on slide after dissociation. Unsuitable manipulation could lead to loss, damage or overlap of chromosomes. On the other hand, a squashed tissue could be easily insufficiently spread and then the chromosomes on slides could be poorly, or not at all analyzable, or even the tissue can be lost during coverslip removing. The use of squashing can be very problematic in organisms with high chromosome number.

The spreading is generally an easier technique, which provides slightly better results than the squashing technique and often provides abundant slides with well-dispersed cells suitable for further analysis. Therefore, gonad tissue spreading is a suitable method for the cytogenetic analysis of Heteroptera, particularly with focus on the small, variable and numerous holokinetic chromosomes of $C$. lectularius. The main advantages and disadvantages of the two methods are summarised in Table 1.

Table I. Summary of general advantages and disadvantages of the hotplate spreading and squashing methods of chromosome preparation.

\begin{tabular}{|c|c|c|}
\hline & Spreading & Squashing \\
\hline \multirow[b]{2}{*}{ Material } & - must be killed freshly & + can be fixed in field \\
\hline & $\begin{array}{l}\text { - keep it alive, store it for short time } \\
\text { (month) }\end{array}$ & + store it for months or longer \\
\hline Equipment & $\begin{array}{l}+ \text { possible to perform it in the field } \\
\text { (need of electricity) }\end{array}$ & $\begin{array}{l}\text { - not possible to perform it in the field (need of } \\
\text { solid } \mathrm{CO}_{2} \text { or liquid N) }\end{array}$ \\
\hline \multirow[b]{2}{*}{ Overall difficulty } & + lower & - higher \\
\hline & $\begin{array}{l}\text { + just handle to move with droplet on } \\
\text { slide properly with fine tungsten } \\
\text { needles }\end{array}$ & $\begin{array}{l}\text { - cells must be in chromosomes on slide is } \\
\text { hardly analyzable single layer, if not }\end{array}$ \\
\hline \multirow[t]{2}{*}{ Results } & $\begin{array}{l}+ \text { even on material rich slides is only } \\
\text { single layer of cells }\end{array}$ & $\begin{array}{l}\text { - on material rich slides is high probability of } \\
\text { overlap }\end{array}$ \\
\hline & + i.e. more analyzable nuclei & - i.e. fewer analyzable nuclei \\
\hline
\end{tabular}




\section{Tissue suitability and results obtained}

Cimex lectularius reproduction is acyclic, which is why it is almost impossible to find out the exact age or physiological condition of wild specimens. Negative results from specimens with inactive gonads (absence of cell division) could be caused just by starving. Exact age and condition could be known only in laboratory reared specimens and it is also possible to use eggs or larvae of specific age.

Chromosome slides were made from tissues with the highest mitotic index, which express amount of dividing cells. Meiotic chromosomes could be isolated only from gonad tissue, but mitotic chromosomes should be obtained from all types of proliferating tissues as in insect e.g. hemolymph, epithelium of digestive tract and in holometabolous insect imaginal disc.

Gonads. Generally, tissue of gonads is used for cytogenetical studies, mainly testes (Fig. 1A, D) (e.g. Kuznetsova et al. 2004, Bressa et al. 2009, Grozeva et al. 2010, Poggio et al. 2011, 2014), sometimes ovaries (Fig. 1B, C, E) (e.g. Angus et al. 2004, Waller and Angus 2005). We obtained chromosomes in all various stages of spermatogenesis (mitosis and meiosis) from $C$. lectularius testes, and only mitotic chromosomes in its ovaries. However, also frequent meiotic pachytene cells (Fig. 2E) were recorded in ovaries. This could mean that the female pachytene is a prolonged resting phase when immature oocytes stop meiosis until feeding or mating. In the contrast to females, the pachytene stage in C. lectularius males is very short and its finding is extremely rare.

Gonads from $4^{\text {th }}$ and $5^{\text {th }}$ instar larvae were analyzed as well as those of adults (Fig. $1 \mathrm{~A}-\mathrm{C})$. Gonads of the $4^{\text {th }}$ larval instar are always very small, any manipulation of them is quite difficult as well as a correct determination of sex. Size of the $5^{\text {th }}$ larval instar gonads (Fig. 1D, E) can be different in wide spectrum, from miniature as in the $4^{\text {th }}$ larval instar to large and well developed in sub adult specimens, in which also sex can be distinguished easily. In the older $5^{\text {th }}$ instar larvae, nuclei from mitosis to meiotic metaphase II can be seen (Fig. 2A, B, L).

In $C$. lectularius feeding directly initiates mating behaviour and cell division in gonads, thus this is a required condition for gonad growth and gamete production (Usinger 1966). In our study, small gonads and therefore negative slides were recorded even from recently (approximately 7 days) fully engorged specimens, which probably could not digest their meal and start gamete production.

Testes tissues were shown to be very suitable for the $C$. lectularius cytogenetic research. They contain large quantities of cells in all stages of meiotic and mitotic division and provide enough information for complete karyotype analysis. Ovarian tissue is suitable in cases of lack of males or as a reference in samples with a higher chromosomal variability, and to confirm the sex chromosome system in comparison with chromosomes of males. In samples of $C$. lectularius with variable karyotype, it is interesting to observe complementarity of chromosome number between males and females, and it is also possible to study females with varying $\mathrm{X}$ chromosome numbers in oocytes, originating from breeding of specimens with different karyotypes (Sadílek et al. 2013). 

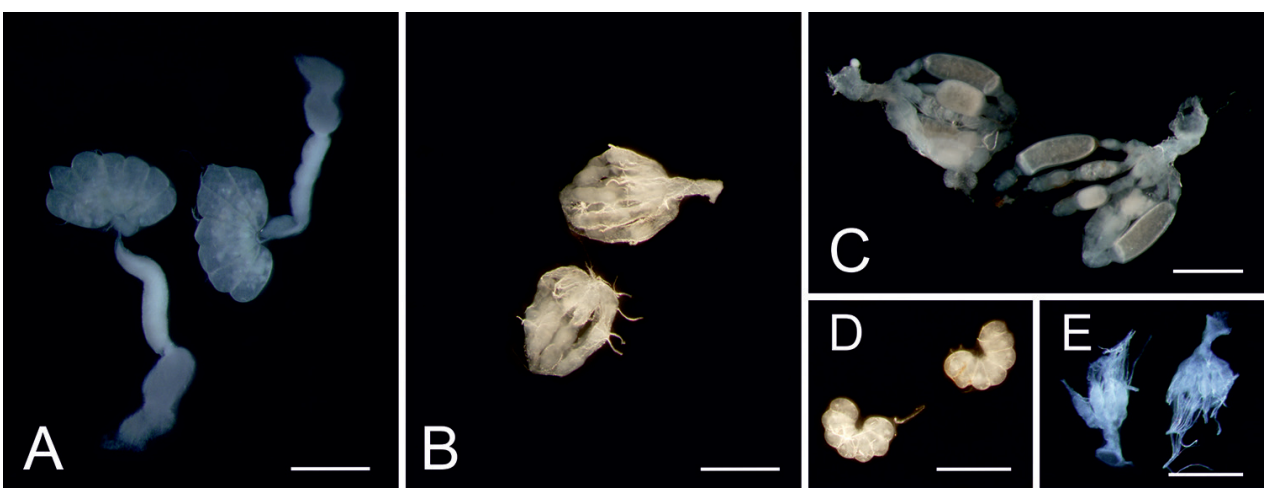

Figure I. Adult and $5^{\text {th }}$ instar larva Cimex lectularius gonads. A Adult testes B Adult ovaries, without eggs $\mathbf{C}$ Adult ovaries, with well-developed eggs $\mathbf{D} 5^{\text {th }}$ instar larva testes, well-developed, probably sub adult specimen $\mathbf{E} 5^{\text {th }}$ instar larva ovaries. Scale bar $=1 \mathrm{~mm}$.

The absence of meiotic metaphases in adult females suggests meiotic division in an earlier instar. However, because of quite frequently recorded pachytene nuclei (Fig. $2 \mathrm{E})$ the whole meiotic division has to take place even in adult females. In the contrast, in testes pachytene chromosomes were recorded very rarely, thus it is possible to propose a different length of the pachytene stage between sexes. It is very possible that the whole phenomenon is connected to male achiasmatic meiosis. Male pachytene checkpoint is missing because of male recombination absence that means the male pachytene is very fast and hard to record (e.g. Tung et al. 2000).

Heteroptera cytogenetics is studied usually on male gonads. Detailed study of female karyotype is often problematic, because there is much lower abundance of dividing cells in ovaries than in testes and because all female meiotic stages are almost impossible to record. These are the main reasons for the absence of information about female cytogenetics especially meiosis (Kuznetsova et al. 2011). Nevertheless, in a case of complicated variable karyotypes of $C$. lectularius, the analysis of female cytogenetics results is important and highly recommended.

Midgut epithelium. This tissue should be suitable for cytogenetic study due to continual wasting of digestive cells, followed by intensive mitotic division and differentiation of the regenerative (= stem) cells (e.g. Azevedo et al. 2009, Rost-Roszkowska et al. 2010a, 2010b). Nevertheless, midgut epithelium slides of C. lectularius contained no countable mitotic chromosomes. Even specimens with rich chromosome slides from gonads provided no records of any chromosomal division in midgut epithelium. We found only one poor nucleus with mitotic chromosomes from 116 slides analysed. It is very interesting that absence of mitosis in midgut is not connected either with presence or absence of food in midgut lumen. Negative slides without distinct particular chromosomes for karyotype study were from specimens with completely full, through all situations, to empty midgut. It could be similar to the case recently described in Ceratopogonidae (Diptera) (Urbanek and Rost-Roszkowska 2015). In 

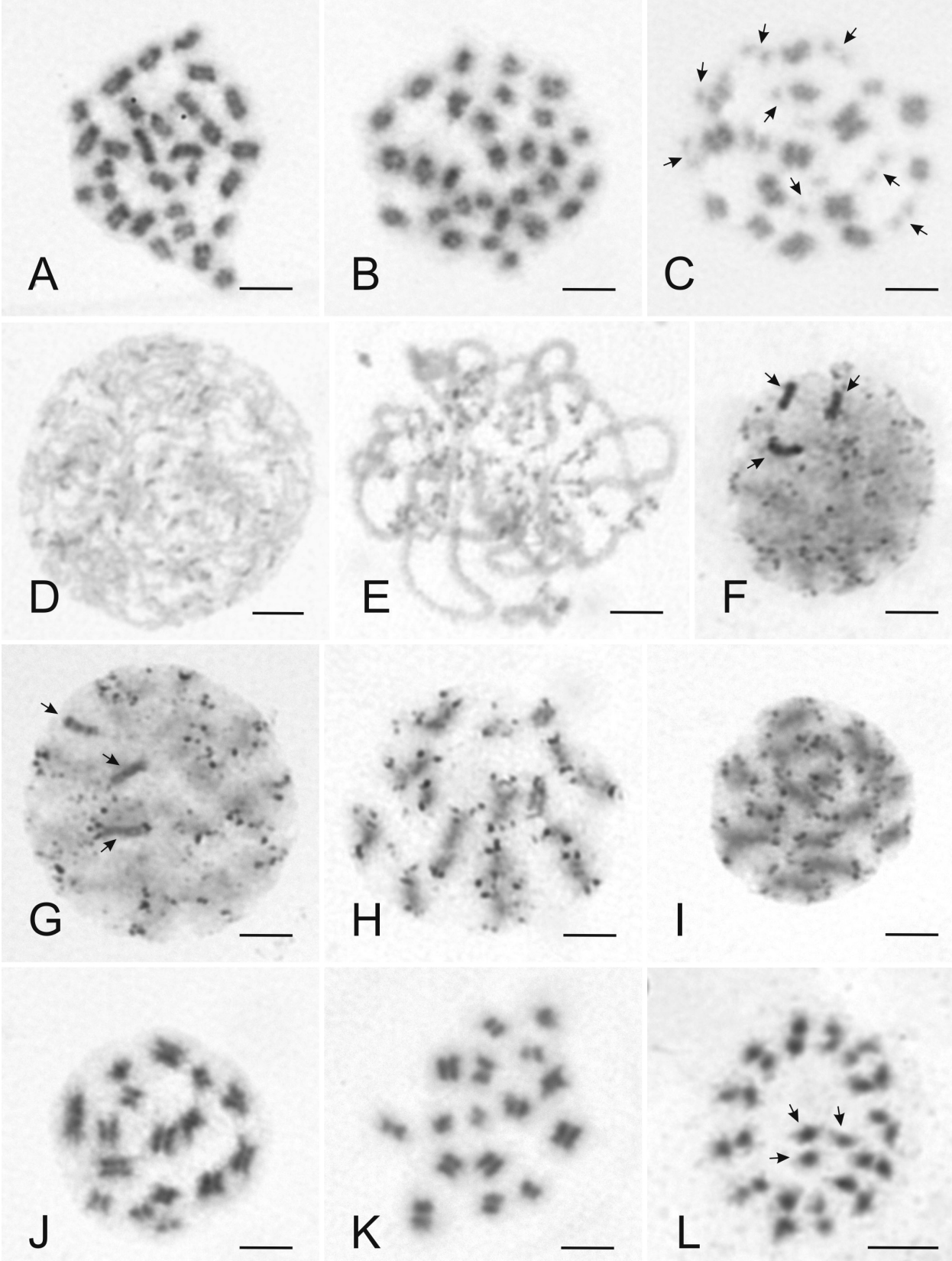

Figure 2. Various stages of mitotic and meiotic Cimex lectularius chromosomes with basic karyotype $2 \mathrm{n}$ $=26+X_{1} X_{2} Y(\mathbf{A}, \mathbf{B}, \mathbf{D}-\mathbf{L})$ and karyotype $2 n=26+X_{1-10} \mathrm{Y}(\mathbf{C})$, stained with Giemsa. A Mitotic prometaphase $\delta$ B Mitotic metaphase $\delta \mathbf{C}$ Metaphase I $\delta \mathbf{D}$ Leptotene $q \mathbf{E}$ Pachytene $q \mathbf{F}$ Diffuse stage $\hat{\sigma}$ G Diffuse stage - postpachytene transition $\delta \mathbf{H}$ Postpachytene $\delta \mathbf{I}$ Late postpachytene $\hat{\delta} \mathbf{J}$ Prometaphase I $\hat{\sigma} \mathbf{K}$ Metaphase I $\hat{\sigma} \mathbf{L}$ Metaphase II $\hat{\partial}$. Arrow $=$ sex chromosome $(\mathbf{F}, \mathbf{G}, \mathbf{L})$ or fragments of supposedly sex chromosomes $(\mathbf{C})$. Scale bar $=5 \mu \mathrm{m}$. 
studied dipterans, gonad maturing induces degeneration of digestive cells of midgut epithelium, which are used as accumulated nutrients and not apparently replaced, because in adult females regenerative cells are very rare. The mitotic division of regenerative cells has not been observed even in larvae in this case, in which the cells are only differentiated. Recently, no mitotic divisions and differentiations of the regenerative cells were observed in midgut epithelium of two Cimex species, C. lectularius and $C$. pipistrelli (Rost-Roszkowska et al. 2016).

It is more complicated to obtain mitotic chromosomes from midgut epithelium than from gonad tissue in general. The use of colchicine or other mitosis-inhibiting agents, which abolish spindle formation and leave the chromosomes free in the cell, as in the studies of Angus et al. (2004) and Waller and Angus (2005) is necessary for clear chromosome preparations. Colchicine is not a mitostatic when applied to whole insects or embryos, but allows the chromosomes to continue their mitotic cycle (contraction, separation of chromatids, re-elongation) while lying free in the cell. However, our completely negative results suggest that the $C$. lectularius midgut tissue is not suitable for chromosome research even with colchicine treatment.

Eggs. This stage of insect generally contains many tissues with a large amount of mitotic cells of the growing embryo. However, we were not successful in recognizing of these cells on spreaded slides. Three low quality mitoses were recorded on only a single slide from 13 slides analyzed. A serious complication is the unpredictable presence of eggs in wild C. lectularius females, and also the impossibility of distinguishing in advance sex of the embryos. We are sure the sex of embryos only in case of the male basic karyotype $2 \mathrm{n}=26+\mathrm{X}_{1} \mathrm{X}_{2} \mathrm{Y}$, otherwise we are not able to distinguish between male with one more supernumerary chromosome $\left(\mathrm{X}_{1} \mathrm{X}_{2} \mathrm{X}_{3} \mathrm{Y}\right)$ and basic karyotype of female $2 \mathrm{n}=26+\mathrm{X}_{1} \mathrm{X}_{1} \mathrm{X}_{2} \mathrm{X}_{2}$.

The use of eggs is not common in Heteroptera cytogenetics, but for example in study of holokinetic chromosomes in parthenogenetic Psocoptera (Nokkala and Golub 2006), parthenogenetic psyllids and of monocentric chromosomes of Hydrophilidae (Coleoptera) was use of embryonic tissues successful (Angus 1982, Shaarawi and Angus 1991). However, the authors in Hydrophilidae studies used a different modified spreading technique after Crozier (1968).

The karyotype was successfully determined in 128 out of 220 specimens of $C$. lectularius (58\%), 80 males and 48 females, from 140 positive chromosomal slides (34\%) (with cells in division) out of 412 examined. Slides prepared from testes tissue gave the best results, 90 positive slides out of 170 (53\%). Ovarian tissue contains only mitosis with a lower number of 50 positive slides out of 111 (45\%). However, the tissues of midgut and eggs were surprisingly unsuccessful, with only 2 positive slides out of $125(1.6 \%)$. All slides were treated identically, therefore a ratio between positive and negative slides could show percentage of specimens in ideal physiological state for getting mitotic and meiotic chromosomes. 


\section{Chromosome division phases studied}

The following stages of cell division were observed with various frequencies in C. lectularius males. Mitotic cells were recorded especially in metaphase and prometaphase stages (Fig. 2A, B) in $80 \%$ of specimens. Leptotene and pachytene stages were detected only in two specimens. In late prophase I, the most frequent meiotic cells were diffuse stage in $90 \%$ of specimens and postpachytene in 30\% of specimens (Fig. 2F-I). Less frequently, cells in metaphase I (Fig. 2K) were observed in $25 \%$ of specimens, and cells in metaphase II (Fig. 2L) were the most rare, only in $20 \%$ of specimens. Metaphases I were frequently very abundant in the specimens, in a contrast short lasting stages of prometaphase I (Fig. 2J) and II were observed always in small amounts and only in a four specimens.

On slides from ovary cells in mitotic metaphase stage (100\% of specimens) only early prophase I (leptotene and pachytene) (Figs 2D, E) from meiotic division were detected. Leptotene nuclei were recorded only in $10 \%$ of specimens, pachytene nuclei were observed in $50 \%$ of specimens in small densities only. In females no cells were observed in late meiosis, which was the main stage of male cells.

Leptotene (Fig. 2D) and pachytene (Fig. 2E) nuclei are isopycnotic and did not show any distinct features. At diffuse stage (Fig. 2F), autosomes are decondensed and the sex chromosomes are distinctly positive heteropycnotic. During transition from diffuse stage to postpachytene (Fig. 2G), the sex chromosomes become isopycnotic and cannot be distinguished from autosomes. Postpachytene may be considered as meiotic prophase stage that substitutes diplotene and diakinesis in organisms with achiasmatic meiosis where no recombination occurs. During postpachytene, autosomes condensate again and dark terminal spots on telomeric regions of each chromatid appear (Fig, 2G-I). The dark spots disappear at the end of postpachytene, and from prometaphase onwards the chromosomes are isopycnotic (Fig. 2J) and continue in condensation until metaphase I.

In metaphase I (Fig. 2K), nucleus with basic karyotype $2 \mathrm{n}=26+\mathrm{X}_{1} \mathrm{X}_{2} \mathrm{Y}$ shows 13 autosomal bivalents and three sex chromosomes, which do not pair with each other. Male metaphase II is radial, the 13 autosomes dispose in a ring configuration and the $\mathrm{X}_{1}, \mathrm{X}_{2}$ and $\mathrm{Y}$ chromatids form a pseudotrivalent, which lies at the centre of it (Fig. 2L), in concordance with observation of Ueshima (1967), Grozeva et al. (2010) and Sadílek et al. (2013). Metaphase II is the only stage in which it is possible to definitely distinguish autosomes and sex chromosomes. The chromosome arrangement of metaphase II precisely matches the inverted meiosis of sex chromosomes, in which reductional division of autosomal bivalents occurs in anaphase I whereas the sex chromosomes segregate chromatids (equational division). In anaphase II, autosomes segregate sister chromatids, and the $X_{1}$ and $X_{2}$ chromatids segregate from the $Y$ (Ueshima 1966, 1979, Grozeva et al. 2010), even with $20 \mathrm{X}$ supernumerary sex chromosomes (Sadílek et al. 2013) (Fig. 2C). Only the metaphase II reflects clearly number of sex chromosomes in C. lectularius with supernumerary sex chromosome fragments, because this is the only phase where autosomes and sex chromosomes can be distinguished. 
Chromosome number determination is notably easier in meiotic metaphase I and II than in mitosis, because chromosomes are paired and superspiralized. These results show that, using the spreading method, it is possible to get mitotic and meiotic chromosome slides in high quality for further analysis.

\section{Karyogram assembly}

Well-spread mitotic chromosomes can be used to assemble karyograms. A particular requirement here is that chromosomes are not physically stretched in the course of preparations, as can happen with squashes. A karyogram represents standard format of species karyotype image that helps us to distinguish chromosomes, generally specific pairs of autosomes and sex chromosomes (e.g. Angus et al. 2015). The chromosomes are usually ordered by size, position of centromere and some specific marker on chromosomes (e.g. C-bands, G-bands, DAPI/CMA fluorescent bands, Ag-NOR bands or position of specific genes visualized by FISH) (Marco et al. 2009, Maryańska-Nadachowska et al. 2012, Chirino et al. 2015). However, in Heteroptera the holokinetic organization and the chromosome composition do not allow to use many of these cytogenetic features. Besides, some characters may be so variable that the comparison is very complicated, especially between different stages of mitotic or meiotic divisions. For example, the size of chromosomes can vary distinctively according spiralization in various phases. That is a reason the relative size of chromosomes (percentage of single chromosome length from whole karyotype) is used more frequently. In this case, it is necessary to measure all the chromosomes in a great number of cells at the same division stage, i.e. at metaphase I, or at metaphase II, or at spermatogonial metaphase (e.g. Sakamoto and Zacaro 2009, Chirino et al. 2013, 2014, Sadílek et al. 2015).

We assembled three examples of karyograms from $C$. lectularius mitotic chromosomes from different chromosome number of $2 \mathrm{n}=29,33$ and 37 (Fig. 3A-C) and two male meiotic karyograms from prometaphase II and metaphase II, $2 \mathrm{n}=26+\mathrm{X}_{1} \mathrm{X}_{2} \mathrm{Y}$ (Fig. 3D) and $2 \mathrm{n}=26+\mathrm{X}_{1-7} \mathrm{Y}$ (Fig. 3E), respectively. In these cases the size of chromosomes was measured trying to find out the fragmentation events - decreasing size of the $\mathrm{X}$ chromosomes during increasing of their number. Nuclei in mitotic prometaphase provide the most relaxed and still quite compact chromosomes, thus the best stage for getting karyograms (Fig. 3A-C). In the contrast, chromosomes in both meiotic metaphases I and II are globular and very similar to each other (Fig. 3D, E). Moreover, $C$. lectularius chromosomes do not show any strong morphological pattern, and distinguishing pairs of autosomes and sex chromosomes is not easy. In the mitotic prometaphase, we are able to put together some chromosomal pairs according to heteropycnotic regions on the ends of chromosomes visible just after regular Giemsa stain (Fig. 3A-C). The pattern of chromosomes change a little among different karyograms, so it is not possible to use it as a clear diagnostic feature. The sex chromosomes can be quickly recognised only in metaphase II (Figs 2L, 3D, E). 


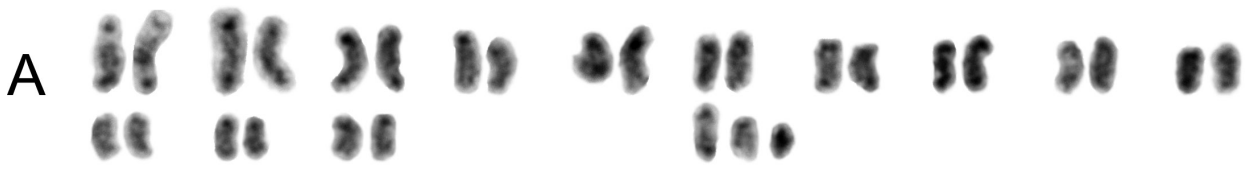

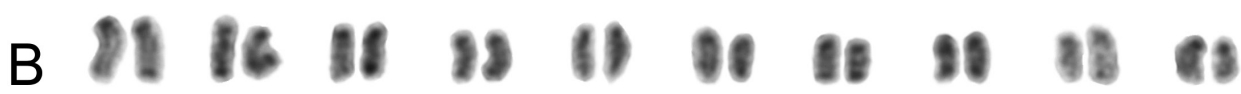 (n) is at ateor.

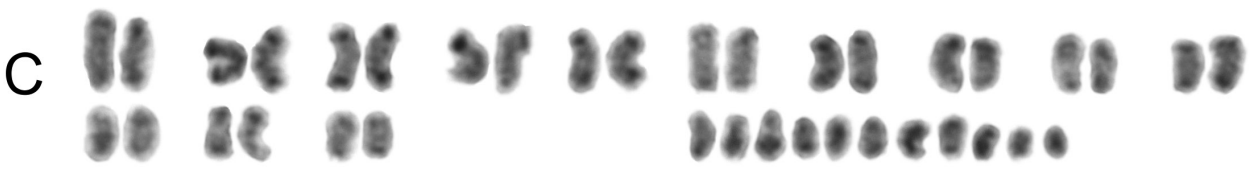

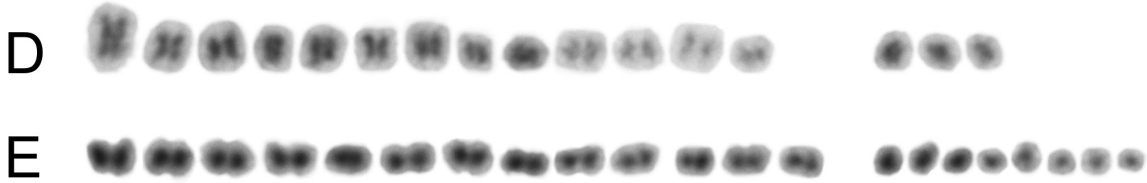

Figure 3. Male mitotic and meiotic karyograms of Cimex lectularius chromosome variants. A-C Mitotic prometaphase. A $2 n=26+X_{1} X_{2} Y$ B $2 n=26+X_{1-6} Y$ C $2 n=26+X_{1-10} Y$ D Prometaphase II, $2 n=26+X_{1} X_{2} Y$ E Metaphase II, $2 \mathrm{n}=26+\mathrm{X}_{1-7} \mathrm{Y}$. Scale bar $=5 \mu \mathrm{m}$.

In each of $C$. lectularius karyotypes the size of chromosomes gradually decreases. That is a reason why the size expressed only as a percentage is not very suitable for karyotype comparison among congeneric species with different diploid chromosome numbers because they have different distribution of length. However, in case of $C$. lectularius chromosome fragments we can predict their very small size as on example of metaphase I with $2 \mathrm{n}=26+\mathrm{X}_{1-10} \mathrm{Y}$ (Fig. 2C). In the contrast two karyograms show additional sex chromosomes (Fig. 3B, C) of almost the same size as the sex chromosomes in karyotype with basic chromosome number (Fig. 3A). It suggests an occurrence of non-disjunction or even possibility of chromosome fragments different spiralization. Another explanation could be the fragments resulted from fragmentation in different parts of the original sex chromosomes. If fragments origin is independent in various populations, they simply cannot be identical and must differ by size and content. All these hypotheses need further study. The karyogram assembly brought us at least rough chromosome size comparison of $C$. lectularius various karyotypes.

\section{Conclusion}

The hotplate spreading technique has many advantages in comparison with the squashing technique. It is suitable for use by cytogenetic beginners as they need only to 
get the manual skill in suspension droplet movement on slide. One disadvantage of spreading exists - material has to be prepared freshly after killing, either in the field or after keeping alive in a lab. However, C. lectularius is capable to survive in good health several months without any meal. The spreading technique seems to be ideal for study of specimens with numerous holokinetic chromosomes.

Tissue of testes, the usual material for insect cytogenetic studies, appeared to be the most suitable also in chromosome study of $C$. lectularius. Ovaries sometimes also show some interesting results. But the tissue of midgut and eggs - supposedly suitable, did not show any satisfactory results.

Results based on ovarian tissue could be easily misinterpreted. During dissociation, cells from ovaries and developing male and female embryos resulted from mating with unknown karyotype male could be mixed. Thus it is possible to observe artificial heterogenic sample of three karyotypes, which can be misleadingly considered as a variability in one female karyotype. This is made possible thanks to cimicid specific traumatic insemination and egg fertilization directly in ovarioles, whole effect could be also magnified by low abundance of mitotic nuclei in ovarian tissue in general. To avoid this problem would be necessary to separate only germarium, part of ovaries where mitosis give rise to primary oocytes.

Meiotic metaphase II is the best division phase for study of chromosomes in C. lectularius, but mitotic prometaphase and metaphase I are also usable. Our suggestion that the abundant nuclei in diffuse stage could serve for quick diagnosis of sex chromosome number was not proved. Nuclei of specimens with higher number of sex chromosomes did not show clear number of heteropycnotic sex chromosome elements. The explanation could be either that spiralization of sex chromosome fragments has changed so they are no more positively heteropycnotic during diffuse stage, or too small size of fragments.

\section{Acknowledgements}

We would like to express special thanks to María José Bressa for valuable advice. We are greatly obliged to all specialists who helped us with sampling of bed bugs: A. Drozda, P. Dvořák, P. Foltán, S. Kováč, M. Kučera, V. Měř́nský, M. Novotný, L. Pěček, V. Prchal, S. Ritterová, P. Sodomek, R. Šimák, M. Toman, J. Vondráčková and J. Zelená (Czech Republic); L. Duplantier (France), T. Hutson (Great Britain), S. Boscolo (Italy), Ł. Brożek, M. Kadej, P. Szewczyk (Poland), H. Kjellberg, A. Larson (Sweden), E. Krug, M. Schmidt, M. Wegman (Switzerland). We appreciate also great help of pest control managers from Biotech Salzburg (Austria), DDD servis (Czech Republic), Ekolas (Slovakia), Pelias Norsk Skadedyrkontroll (Norway) and Verminex (Poland). We are also grateful to O. Balvín (Czech University of Life Sciences, Prague) for help with material collecting and M. Forman and J. Hadrava (Charles University, Prague) for valuable comments to the manuscript.

This project was supported by the grants no. 267111/2011 and 277815/2015 of the Grant Agency of Charles University and grant of Ministry of Education, Youth and Sports of the Czech Republic no. SVV 260313/2016 to senior author. 


\section{References}

Adilardi RS, Affilastro AAO, Martí DA, Mola LM (2014) Cytogenetic analysis on geographically distant parthenogenetic populations of Tityus trivittatus Kraepelin, 1898 (Scorpiones, Buthidae): karyotype, constitutive heterochromatin and rDNA localization. Comparative Cytogenetics 8(2): 81-92. https://doi.org/10.3897/CompCytogen.v8i2.6461

Angus RB (1982) Separation of two species standing as Helophorus aquaticus (L.) (Coleoptera, Hydrophilidae) by banded chromosome analysis. Systematic Entomology 7(3): 265-281. https://doi.org/10.1111/j.1365-3113.1982.tb00444.x

Angus RB, Angus EM, Jia F, Chen Z, Zhang Y (2015) Further karyosystematic studies of the Boreonectes griseostriatus (De Geer) group of sibling species (Coleoptera, Dytiscidae)characterisation of B. emmerichi (Falkenström, 1936) and additional European data. Comparative Cytogenetics 9(1): 133-144. https://doi.org/10.3897/CompCytogen.v9i1.4463

Angus RB, Kemeny CK, Wood EL (2004) The C-banded karyotypes of the four British species of Notonecta L. (Heteroptera: Notonectidae). Hereditas 140(2): 134-138. https://doi. org/10.1111/j.1601-5223.2004.01815.x

Azevedo DO, Neves CA, Mallet JRDS, Gonçalves TCM, Zanuncio JC, Serrão JE (2009) Notes on midgut ultrastructure of Cimex hemipterus (Hemiptera: Cimicidae). Journal of Medical Entomology 46(3): 435-441. https://doi.org/10.1603/033.046.0304

Balvín O, Munclinger P, Kratochvíl L, Vilímová J (2012) Mitochondrial DNA and morphology show independent evolutionary histories of bedbug Cimex lectularius (Heteroptera: Cimicidae) on bats and humans. Parasitology Research 111(1): 457-469. https://doi. org/10.1007/s00436-012-2862-5

Bardella VB, Dias AL, Giuliano-Caetano L, Ribeiro JRI, Da Rosa R (2012) Sex chromosome differentiation in Belostoma (Insecta: Heteroptera: Belostomatidae). Genetics and Molecular Research 11(3): 2476-2486. https://doi.org/10.4238/2012.May.21.2

Bardella VB, Gaeta ML, Vanzela ALL, Azeredo-Oliviera MTV (2010) Chromosomal location of heterochromatin and $45 \mathrm{~S}$ rDNA sites in four South American triatomines (Heteroptera: Reduviidae). Comparative Cytogenetics 4(2): 141-149. https://doi.org/10.3897/compcytogen.v4i2.50

Booth W, Balvín O, Vargo EL, Vilímová J, Schal C (2015) Host association drives genetic divergence in the bed bug, Cimex lectularius. Molecular Ecology 24(5): 980-992. https:// doi.org/10.1111/mec. 13086

Bressa MJ, Franco MJ, Toscani MA, Papeschi AG (2008) Heterochromatin heteromorphism in Holbymenia rubiginosa (Heteroptera: Coreidae). European Journal of Entomology 105(1): 65-72. https://doi.org/10.14411/eje.2008.009

Bressa MJ, Fumagalli E, Ituarte S, Frassa MV, Larramendy ML (2002b) Meiotic studies in Dysdercus Guérin Méneville, 1831 (Heteroptera: Pyrrhocoridae). II. Evidence on variations of the diffuse stage between wild and laboratory-inbred populations of Dysdercus chaquensis Freiberg, 1948. Hereditas 137(2): 125-131. https://doi.org/10.1034/j.16015223.2002.01650.x

Bressa MJ, Larramendy ML, Papeschi AG (2005) Heterochromatin characterization in five species of Heteroptera. Genetica 124: 307-317. https://doi.org/10.1007/s10709-005-4524-3 
Bressa MJ, Papeschi AG, Fumagalli E, van Doesburg PH, Larramendy M (2003) Cytogenetic and nucleolar meiotic cycle analyses in Dysdercus imitator Blöte, 1931 (Heteroptera, Pyrrhocoridae) from Argentina. Folia Biologica Kraków 51(3/4): 135-141.

Bressa MJ, Papeschi AG, Larramendy ML (2002a) Meiotic studies in Lygaeus alboornatus Blanchard 1852 (Heteroptera, Lygaeidae, Lygaeinae). Caryologia 55(1): 15-19. https://doi.org /10.1080/00087114.2002.10589253

Bressa MJ, Papeschi AG, Toloza AC (2015) Cytogenetic features of human head and body lice (Phthiraptera: Pediculidae). Journal of Medical Entomology 52(5): 918-924. doi: http:// dx.doi.org/10.1093/jme/tjv089

Bressa MJ, Papeschi AG, Vítková M, KubíčkováS, Fuková I, Pigozzi MI, Marec F (2009) Sex chromosome evolution in cotton stainers of the genus Dysdercus (Heteroptera: Pyrrhocoridae). Cytogenetic and Genome Research 125: 292-305. https://doi.org/10.1159/000235936

Bueno D, Palacios-Gimenez OM, Cabral-de-Mello DC (2013) Chromosomal mapping of repetitive DNAs in the grasshopper Abracris flavolineata reveal possible ancestry of the B chromosome and H3 histone spreading. PLoS ONE 8(6): e66532. https://doi. org/10.1371/journal.pone.0066532

Cabral-de-Mello DC, Moura RC, Martins C (2010) Chromosomal mapping of repetitive DNAs in the beetle Dichotomius geminatus provides the first evidence for an association of $5 \mathrm{~S}$ rDNA and histone $\mathrm{H} 3$ genes in insects, and repetitive DNA similarity between the B chromosome and A complement. Heredity 104: 393-400. https://doi.org/10.1038/ hdy.2009.126

Chirino MG, Bressa MJ (2014) Karyotype evolution in progress: A new diploid number in Belostoma candidulum (Heteroptera: Belostomatidae) from Argentina leading to new insights into its ecology and evolution. European Journal of Entomology 111(2): 165-174. https:// doi.org/10.14411/eje.2014.027

Chirino MG, Papeschi AG, Bressa MJ (2013) The significance of cytogenetics for the study of karyotype evolution and taxonomy of water bugs (Heteroptera, Belostomatidae) native to Argentina. Comparative Cytogenetics 7(2): 9-27. https://doi.org/10.3897/compcytogen. v7i2.4462

Chirino MG, Rossi LF, Bressa MJ, Luaces JP, Merani MS (2015) Comparative study of mitotic chromosomes in two blowflies, Lucilia sericata and L. cluvia (Diptera, Calliphoridae), by C- and G-like banding patterns and rRNA loci, and implications for karyotype evolution. Comparative Cytogenetics 9(1): 103-118. https://doi.org/10.3897/CompCytogen. v9i1.8671

Crozier RH (1968) An acetic acid dissociation, air-drying technique for insect chromosomes, with aceto-lactic orcein staining. Stain Technology 43(3): 171-173. https://doi. org/10.3109/10520296809115063

Darlington CD (1939) The genetical and mechanical properties of the sex chromosomes. V. Cimex and the Heteroptera. Journal of Genetics 39(1): 101-137. https://doi.org/10.1007/ BF02982821

Forman M, Nguyen P, Hula V, Král J (2013) Sex chromosome pairing and extensive NOR polymorphism in Wadicosa fidelis (Araneae: Lycosidae). Cytogenetic and Genome Research 141(1): 43-49. https://doi.org/10.1159/000351041 
Green JE, Dalíková M, Sahara K, Marec F, Akam M (2016) XX/XY system of sex determination in the geophilomorph centipede Strigamia maritima. PLoS ONE 11(2): e0150292. https://doi.org/10.1371/journal.pone.0150292

Grozeva S, Kuznetsova V, Anokhin B (2010) Bed bug cytogenetics: karyotype, sex chromosome system, FISH mapping of $18 S$ rDNA, and male meiosis in Cimex lectularius Linnaeus, 1758 (Heteroptera: Cimicidae). Comparative Cytogenetics 4(2): 151-160. https:// doi.org/10.3897/compcytogen.v4i2.36

Grozeva S, Kuznetsova V, Anokhin B (2011) Karyotypes, male meiosis and comparative FISH mapping of $18 \mathrm{~S}$ ribosomal DNA and telomeric (TTAGG)n repeat in eight species of true bugs (Hemiptera, Heteroptera). Comparative Cytogenetics 5(4): 355-374. https://doi. org/10.3897/CompCytogen.v5i4.2307

Grozeva S, Nokkala S (1996) Chromosomes and their meiotic behavior in two families of the primitive infraorder Dipsocoromorpha (Heteroptera). Hereditas 125(1): 31-36. https:// doi.org/10.1111/j.1601-5223.1996.t01-1-00031.x

Grozeva S, Nokkala S (2002) Achiasmatic male meiosis in Cimex sp. (Heteroptera, Cimicidae). Caryologia 55(3): 189-192. https://doi.org/10.1080/00087114.2002.10589276

Grozeva S, Simov N, Nokkala S (2008) Achiasmatic male meiosis in three Micronecta species (Heteroptera: Nepomorpha: Micronectidae). Comparative Cytogenetics 2(1): 73-78. http://www.zin.ru/journals/compcyt/pdf/2/grozeva.pdf?Similar30

Guerra M, Cabral G, Cuacos M, González-García M, González-Sánchez M, Vega J, Puertas MJ (2010) Neocentrics and holokinetics (holocentrics): Chromosomes out of the centromeric rules. Cytogenetic and Genome Research 129: 82-96. https://doi.org/10.1159/000314289

Howe M, McDonald KL, Albertson DG, Meyer BJ (2001) HIM-10 is required for kinetochore structure and function on Caenorhabditis elegans holocentric chromosomes. The Journal of Cell Biology 153(6): 1227-1238. https://doi.org/10.1083/jcb.153.6.1227

Hwang SW, Svoboda TJ, De Jong IJ, Kabasele KJ, Gosis E (2005) Bed bug infestations in an urban environment. Emerging Infectious Diseases 11(4): 533-538. https://doi.org/10.3201/ eid1104.041126

Imai HT, Taylor RW, Crosland MWJ, Crozier RH (1988) Modes of spontaneous chromosomal mutation and karyotype evolution in ants with reference to minimum interaction hypothesis. Japanese Journal of Genetics 63(2): 159-185. doi: http://doi.org/10.1266/jjg.63.159

Ituarte S, Papeschi AG (2004) Achiasmatic male meiosis in Tenagobia (Fuscagobia) fuscata (Stål) (Heteroptera, Corixoidea, Micronectidae). Genetica 122(2): 199-206. https://doi. org/10.1023/B:GENE.0000041048.75715.68

Koller PC (1935) The internal mechanics of the chromosomes. IV.- Pairing and coiling in salivary gland nuclei of Drosophila. Proceedings of the Royal Society of London. Series B, biological Sciences 118: 371-397. http://www.jstor.org/stable/81900

Korschelt E (1884) Über die eigentümliche Bildung in den Zellkernen der Speicheldrüse von Chironomus plumosa. Zoologischer Anzeiger 7: 189-194. http://biodiversitylibrary.org/ page/30123669

Kořínková T, Goldyn B (2011) Karyotypes and sex ratios in population of Eubranchipus grubii (Dybowski, 1860) and Branchipus schaefferi Fischer, 1834 (Branchiopoda, Anostraca) from Poland. Crustaceana 84(5-6): 707-720. https://doi.org/10.1163/001121611X577918 
Kuznetsova VG, Grozeva SM, Hartung V, Anokhin BA (2015) First evidence for (TTAGG) $\mathrm{n}$ telomeric sequence and sex chromosome post-reduction in Coleorrhyncha (Insecta, Hemiptera). Comparative Cytogenetics 9(4): 523-532. https://doi.org/10.3897/CompCytogen.v9i4.5609

Kuznetsova VG, Grozeva S, Nokkala S (2004) New cytogenetic data on Nabidae (Heteroptera: Cimicomorpha), with a discussion of karyotype variation and meiotic patterns, and their taxonomic significance. European Journal of Entomology 101(2): 205-210. https://doi. org/10.14411/eje.2004.026

Kuznetsova VG, Grozeva SM, Nokkala S, Nokkala C (2011) Cytogenetics of the true bug infraorder Cimicomorpha (Hemiptera, Heteroptera): a review. ZooKeys 154: 31-70. https://doi.org/10.3897/zookeys.154.1953

Kuznetsova VG, Maryańska-Nadachowska A (2000) Autosomal polyploidy and male meiotic pattern in the bug family Nabidae (Heteroptera). Journal of Zoological Systematics and Evolutionary Research 38(2): 87-94. https://doi.org/10.1046/j.1439-0469.2000.382131.x

Lanzone C, de Souza MJ (2006) Chromosome complement and meiosis in three species of the Neotropical bug genus Antiteuchus (Heteroptera, Pentatomidae, Discocephalinae). Genetics and Molecular Biology 29(1): 49-55. http://dx.doi.org/10.1590/S1415-47572006000100011

Leston D (1957) Cytotaxonomy of Miridae and Nabidae (Hemiptera). Chromosoma 8(1): 609-616. https://doi.org/10.1007/BF01259522

Mandrioli M, Manicardi GC (2003) Analysis of insect holocentric chromosomes by atomic force microscopy. Hereditas 138(2): 129-132. https://doi.org/10.1034/j.1601-5223.2003.01661.x

Manna GK (1984) Chromosomes in evolution in Heteroptera. In: Sharma AK, Sharma A (Eds) Chromosomes in evolution of eukaryotic groups. CRC Press, Boca Raton, Florida, 189-225.

Marco R, Cassenelli S, Mazzoni E, Bizzaro D, Manicardi CG (2009) Heterochromatin and rDNA localization on the holocentric chromosomes of black bean aphid, Aphis fabae Scop. (Hemiptera: Aphididae). Caryologia 62(4): 341-346. https://doi.org/10.1080/00087114 .2004.10589700

Maryańska-Nadachowska A, Kuznetsova VG, Lachowska D, Drosopoulos S (2012) Mediterranean species of the spittlebug genus Philaneus: Modes of chromosome evolution. Journal of Insect Science 12(1): 54. https://doi.org/10.1673/031.012.5401

McClung CE (1899) A peculiar nuclear element in the male reproductive cells of insects. Zoological Bulletin 2(4): 187-197. https://doi.org/10.2307/1535425

Mola LM, Papeschi AG (2006) Holokinetic chromosomes at glance. Journal of Basic \& Applied Genetics 17(1): 17-33. https://www.researchgate.net/publication/233962459_ Holokinetic_chromosomes_at_a_glance

Montgomery TH (1901) A study of the chromosomes of the germ cells of metazoa. Transactions of the American Philosophical Society 20(2): 154-236. https://doi.org/10.2307/1005428

Morielle-Souza A, Azeredo-Oliveira MTV (2007) Diferential characterization of holocentric chromosomes in triatomines (Heteroptera, Triatominae) using different staining techniques and fluorescent in situ hybridization. Genetics and Molecular Research 6(3): 713-720. http://www.geneticsmr.com/articles/396

Motzko D, Ruthmann A (1984) Spindle membranes in mitosis and meiosis of the heteropteran insect Dysdercus intermedius. A study of the interrelationship of spindle architecture 
and the kinetic organization of chromosomes. European Journal of Cell Biology 33(2): 205-216.

Nokkala C, Kuznetsova VG, Nokkala S (2015) Rare diploid females coexist with rare males: a novel finding in triploid parthenogenetic populations in the psyllid Cacopsylla myrtilli (W. Wagner, 1947) (Hemiptera, Psylloidea) in northern Europe. Genetica 143(5): 589-595. https://doi.org/10.1007/s10709-015-9858-x

Nokkala S, Golub NV (2006) Automictic and apomictic parthenogenesis in psocids (Insecta: Psocoptera). Folia Biologica (Kraków) 54: 19-22. https://doi. org/10.3409/173491606777919193

Nokkala S, Grozeva S (2000) Achiasmatic male meiosis in Myrmedobia coleoptrata (Fn.) (Heteroptera, Microphysidae). Caryologia 53(1): 5-8. https://doi.org/10.1080/00087114.200 0.10589176

Nokkala S, Nokkala C (1983) Achiasmatic male meiosis in two species of Saldula (Saldidae, Hemiptera). Hereditas 99(1): 131-134. https://doi.org/10.1111/j.1601-5223.1983. tb00737.x

Novotná J, Havelka J, Starý P, Koutecký P, Vítková M (2011) Karyotype analysis of the Russian wheat aphid, Diuraphis noxia (Kurdjumov) (Hemiptera: Aphididae) reveals a large X chromosome with rRNA and histone gene families. Genetica 139(3): 281-289. https:// doi.org/10.1007/s10709-011-9546-4

Paladino LC, Papeschi AG, Lanzavecchia S, Cladera JL, Bressa MJ (2013) Cytogenetic characterization of Diachasmimorpha longicaudata (Hymenoptera: Braconidae), a parasitoid wasp used as a biological control agent. European Journal of Entomology 110(3): 401-409. https://doi.org/10.14411/eje.2013.054

Papeschi AG, Bressa MJ (2006) Classical and molecular cytogenetics in Heteroptera. Research Advances in Entomology 1: 1-9.

Parshad R (1957) A comparative study of the chromosomes in the male germ-cells of eleven species of the sub-family Pentatominae. Research Bulletin of the Panjab University 122: 401-420.

Pérez R, Calleros L, Rose V, Lorca M, Panzera F (2004) Cytogenetic studies on Mepraia gajardoi (Heteroptera: Reduviidae). Chromosome behaviour in a spontaneous translocation mutant. European Journal of Entomology 101(2): 211-218. https://doi.org/10.14411/ eje. 2004.027

Piza ST (1957) The chromosomes of Rhopalurus (Scorpiones-Buthidae). The Canadian Entomologist 89(12): 565-568. https://doi.org/10.4039/Ent89565-12

Poggio MG, Bressa MJ, Coscarón MC, Papeschi AG (2006) Cytogenetic characterization of three species of Harpactorinae (Reduviidae, Heteroptera, Insecta) (Ciudad Autónoma de Buenos Aires). Biocell 31(2): 340.

Poggio MG, Bressa MJ, Papeschi AG (2011) Male meiosis, heterochromatin characterization and chromosomal location of rDNA in Microtomus lunifer (Berg, 1900) (Hemiptera: Reduviidae: Hammacerinae). Comparative Cytogenetics 5(1): 1-22. https://doi.org/10.3897/ compcytogen.v5i1.1143

Poggio MG, Bressa MJ, Papeschi AG, Di Iorio O, Turienzo P (2009) Insects found in birds' nests from Argentina: cytogenetic studies in Cimicidae (Hemiptera) and its taxonomical and phylogenetic implications. Zootaxa 2315: 39-46. doi: http://dx.doi.org/10.11646/\%25x 
Poggio MG, Di Iorio O, Turienzo P, Papeschi AG, Bressa MJ (2014) Heterochromatin characterization and ribosomal gene location in two monotypic genera of bloodsucker bugs (Cimicidae, Heteroptera) with holokinetic chromosomes and achiasmatic meiosis. Bulletin of Entomological Research 104(6): 788-793. doi: http://dx.doi.org/10.1017/ S0007485314000650

Poggio MG, Gaspe MS, Papeschi AG, Bressa MJ (2013a) Cytogenetic study in a mutant of Triatoma infestans (Hemiptera: Reduviidae) carrying a spontaneous autosomal fusion and an extra chromosome. Cytogenetic and Genome Research 139(1): 44-51. https://doi. org/10.1159/000342875

Poggio MG, Yael MP, Papeschi AG, Bressa MJ (2013b) Possible origin of polymorphism for chromosome number in the assassin bug Zelurus femoralis longispinis (Reduviidae: Reduviinae). Biological Journal of the Linnean Society 110(4): 757-764. https://doi.org/10.1111/bij.12168 Rebagliati PJ, Mola LM, Papeschi AG (2001) Karyotype and meiotic behaviour of the holokinetic chromosomes of six Argentine species of Pentatomidae (Heteroptera). Caryologia 54(4): 339-347. https://doi.org/10.1080/00087114.2001.10589245

Rebagliati PJ, Mola LM, Papeschi AG, Grazia J (2005) Cytogenetic studies in Pentatomidae (Heteroptera): A review. Journal of Zoological Systematics and Evolutionary Research 43(3): 199-213. https://doi.org/10.1111/j.1439-0469.2005.00312.x

Reinhardt K, Harder A, Holland S, Hooper J, Leake-Lyall C (2008) Who knows the bed bug? Knowledge of adult bed bug appearance increases with people's age in three counties of Great Britain. Journal of Medical Entomology 45(5): 956-958. https://doi. org/10.1603/0022-2585(2008)45[956:WKTBBK]2.0.CO;2

Romero A, Potter MF, Potter DA, Haynes KF (2007) Insecticide resistance in the bed bug: A factor in the pest's sudden resurgence? Journal of medical Entomology 44(2): 175-178. https://doi.org/10.1093/jmedent/44.2.175

Rost-Roszkowska MM, Jansta P, Vilimova J (2010a) Fine structure of the midgut epithelium in two Archaeognatha, Lepismachilis notata and Machilis hrabei (Insecta) in relation to its degeneration and regeneration. Protoplasma 247(1): 91-101. https://doi.org/10.1007/ s00709-010-0148-2

Rost-Roszkowska MM, Vilimova J, Chajec $€$ (2010b) Fine structure of the midgut epithelium of Atelura formicaris (Hexapoda: Zygentoma: Ateluridae), with special references to its regeneration and degeneration. Zoological Studies 49(1): 10-18. http://zoolstud.sinica. edu.tw/Journals/49.1/10.pdf

Rost-Roszkowska MM, Vilimova J, Włodarczyk A, Sonakowska L, Kamińska K, Kaszuba F, Marchewka A, Sadílek D (2016) Investigation of the midgut structure and ultrastructure in Cimex lectularius and Cimex pipistrelli (Hemiptera: Cimicidae). Neotropical Entomology. https://doi.org/10.1007/s13744-016-0430-x

Sadílek D, Nguyen P, Koç H, Kovařík F, Yağmur EA, Štáhlavský F (2015) Molecular cytogenetics of the Androctonus scorpions: Oasis of calm in turbulent karyotype evolution of the diverse family Buthidae. Biological Journal of the Linnean Society 115(1): 69-76. https:// doi.org/10.1111/bij.12488

Sadílek D, Štáhlavský F, Vilímová J, Zima J (2013) Extensive fragmentation of the X chromosome in the bed bug Cimex lectularius Linnaeus, 1758 (Heteroptera, Cimicidae): a survey across Europe. Comparative Cytogenetics 7(4): 253-269. https://doi.org/10.3897/CompCytogen.v7i4.6012 
Sakamoto Y, Zacaro AA (2009) LEVAN, an ImageJ plugin for morphological cytogenetics analysis of mitotic and meiotic chromosomes. http://rsbweb.nih.gov/ij/plugins/levan/levan.html [accessed: 8.2.2016]

Sáez FA (1950) Una técnica para el estudio de los cromosomas somáticos largos en los vegetales. Cien e Inv 6: 281-282.

Schvarzstein M, Wignall SM, Villeneuve AM (2010) Coordinating cohesion, co-orientation, and congression during meiosis: lessons from holocentric chromosomes. Genes \& Development 24(3): 219-228. https://doi.org/10.1101/gad.1863610

Shaarawi FAI, Angus RB (1991) Chromosomal analysis of some European species of the genus Berosus Leach (Coleoptera: Hydrophilidae). Koleopterologische Rundschau 61: 105-110. http://www.zobodat.at/pdf/KOR_61_1991_0105-0110.pdf

Slack HD (1939) Structural hybridity in Cimex l. Zeitschrift für Zellforschung und Mikroskopische Anatomie. Abteilung B, Chromosoma 1(1): 104-118. https://doi.org/10.1007/ BF01271624

Štáhlavský F, Král J (2004) Karyotype analysis and achiasmatic meiosis in pseudoscorpions of the family Chthoniidae (Arachnida: Pseudoscorpiones). Hereditas 140(1): 49-60. https:// doi.org/10.1111/j.1601-5223.2004.01783.x

Traut W (1976) Pachytene mapping in the female silkworm Bombyx mori L. (Lepidoptera). Chromosoma 58(3): 275-284. https://doi.org/10.1007/BF00292094

Tung KS, Hong EJE, Roeder GS (2000) The pachytene checkpoint prevents accumulation and phosphorylation of the meiosis-specific transcription factor Ndt80. Proceedings of the National Academy of Sciences 97(22): 12187-12192. https://doi.org/10.1073/pnas.220464597

Ueshima N (1963) Chromosome behavior of the Cimex pilosellus complex (Cimicidae: Hemiptera). Chromosoma (Berlin) 14(5): 511-521. https://doi.org/10.1007/BF00321470

Ueshima N (1966) Cytology and cytogenetics. In: Usinger RB (Ed.) Monograph of Cimicidae (Hemiptera - Heteroptera). Entomological Society of America, Maryland, College Park, 183-237.

Ueshima N (1967) Supernumerary chromosomes in the human bed bug Cimex lectularius Linn. (Cimicidae: Hemiptera). Chromosoma (Berlin) 20(3): 311-331. https://doi.org/10.1007/ BF00326188

Ueshima N (1968) Distribution, host relationships and speciation of the genus Paracimex (Cimicidae: Hemiptera). Mushi 42: 15-27.

Ueshima N (1979) Hemiptera II: Heteroptera. In: John B (Ed.) Animal Cytogenetics. Vol. 3: Insecta 6. Gebrüder Borntraeger, Berlin-Stuttgart, V+117.

Urbanek A, Rost-Roszkowska MM (2015) Ultrastructural studies on the midgut of biting midge Forcipomyia nigra (Winnertz) (Diptera: Ceratopogonidae). Micron 69: 25-34. https://doi. org/10.1016/j.micron.2014.11.003

Usinger RB (1966) Monograph of Cimicidae (Hemiptera - Heteroptera). Entomological Society of America, Maryland, College Park, XI+585 pp.

van't Hof AE, Edmonds N, Dalíková M, Marec F, Saccheri IJ (2011) Industrial melanism in british peppered moths has a singular and recent mutational origin. Science 332(6032): 958-960. https://doi.org/10.1126/science.1203043

Viera A, Page J, Rufas JS (2009) Inverted meiosis: The true bugs as a model to study. In: Benavente R, Volff JN (Eds) Genome Dynamics. Vol. 5. Meiosis. Karger, Switzerland, Basel, 137-156.

Waller MS, Angus RB (2005) A chromosomal investigation of the west European species of Corixa Geffroy (Heteroptera: Corixidae). Genetica 125(1): 17-25. https://doi.org/10.1007/ s10709-005-1468-6 
Warren ME, Gassner G, Breland OP (1960) Somatic chromosomes of praying mantids as shown by the squash technique. Texas Reports on Biology and Medicine 18: 674-679.

Weeks ENI, Logan JG, Gezan SA, Woodcock CM, Birkett MA, Pickett JA, Cameron MM (2010) A bioassay for studying behavioural responses of the common bed bug, Cimex lectularius (Hemiptera: Cimicidae) to bed bug-derived volatiles. Bulletin of Entomological Research 101(1): 1-8. https://doi.org/10.1017/S0007485309990599

White MJD (1973) Animal cytology and evolution. Cambridge University Press, London, VIII+961 pp.

Wolf KW, Novák K, Marec F (1997) Kinetic organization of metaphase I bivalents in spermatogenesis of Lepidoptera and Trichoptera species with small chromosome numbers. Heredity 79: 135-143. https://doi.org/10.1038/hdy.1997.136

Yang H, Li H, Dai X, Chang J, Cai W (2012) New cytogenetic data on Coreoidea (Hemiptera: Heteroptera) with special reference to Coreidae. Zootaxa 3313: 53-61. 